\title{
Economic Analysis of Adoption of Mulching Technology in Yam Production in Osun State, Nigeria
}

\author{
A. Akinola*, P. Owombo \\ Department of Agricultural Economics, Faculty of Agriculture, Obafemi Awolowo University, Ile-Ife, 220005, Nigeria
}

\begin{abstract}
In addressing the problem of low soil fertility and land degradation occasioned by increased population growth, erosion of soil nutrients and extreme exposure of land to harsh weather conditions resulting in reduced yam yield, mulching technology was adopted by the farmers in Osun State, Nigeria. This study used a multi-stage sampling technique to select 105 farmers involving adopters and non-adopters of mulching technology. Data were analysed with the aid of descriptive statistics, budgetary techniques and probit model. The results of budgetary analysis showed that seed yam and labour costs constituted significant parts of the variable costs. The average revenue per hectare for adopters was $\$ 412,971.69$ while that of non-adopters was $\$ 346,456.75$. However, the average net incomes were $\$ 326,865.02$ and $\$ 236,087.40$ for the adopters and non-adopters, respectively. The benefit-cost ratios were 4.79 and 3.13 for adopters and non-adopters, respectively. The probit model revealed that household size and hired labour were significant factors determining the farmers' adoption decisions. There is therefore the need to encourage farmers on the importance of adopting this land protecting technology and a policy thrust that make seed yam available and affordable as well as reducing the costs incurred on labour will be in the right direction of boosting yam production.
\end{abstract}

Keywords Adoption, Mulching, Yam, Budgetary Technique, Probit

\section{Introduction}

Yam (Dioscorea spp.) forms a basic staple food for millions of people in Nigeria, where it is eaten boiled, roasted, fried and also can be processed into various forms of flour and starchy paste. In the dominant yam production zone of West Africa, consumer demand for yam is generally very high and its cultivation is very profitable despite high production costs[8].

Nigeria is the largest producer of yam (34 million tonnes) but Ghana which is the third largest producer exports the largest quantity of yam about 12000 tonnes[8]. This is due to a number of reasons which include use of soils low in fertility and quality fertility and hence quality of yam produced in Nigeria is very poor.

Yams (Dioscorea species) are annual or perennial tuber-bearing and climbing plants. The genus Dioscorea has over 600 species but only a few are cultivated for food. The major edible species of African origin are white Guinea yam (D. rotundata Poir.), yellow Guinea yam (D. cayenensis Lam.), and trifoliate or bitter yam (D. dumetorum Kunth)[8].

It is planted as sole crop but unusually intercropped with melon, pepper, okra and amaranthus. The most important

* Corresponding author:

aakinola2000@yahoo.com (A. Akinola)

Published online at http://journal.sapub.org/ijaf

Copyright (C) 2012 Scientific \& Academic Publishing. All Rights Reserved part of the yam plant is the tuber. It can be grown in all tropical countries provided water is not a limiting factor. In Nigeria, it is grown within the coastal region up to latitude $12^{\circ} \mathrm{N}$ and corresponds to the rain forest, wood savannah and southern savannah belt. This is where the annual rainfall exceeds $800 \mathrm{~mm}$ in amount and 4 months in duration. Deep, fertile, friable, and well-drained soils are ideal for yam cultivation. Whole seed tubers or tuber portions are usually planted into mounds or ridges before or at the beginning of the rainy season. The sett sizes planted, sizes of mounds, interplant spacing and provision of stakes for the resultant plants depend on factors such as the yam species, agro ecology, and tuber sizes desired at harvest. Small-scale farmers in West and Central Africa often intercrop yams with cereals and vegetables.

The labour requirements in yam cultivation for mounding, staking (especially in the forest zone), weeding, and harvesting exceed those for other starchy staples such as cassava[8]. Yam matures 8-12 months after planting (some are cut after 6 months are covered again to act as seed yam). However, increased population, erosion, and adverse weather conditions have reduced available land to yam production, thereby encouraging intensification of land leading to the degradation of land and depletion of soil nutrients that necessitate the use of land improving technologies such as mulching. Therefore, the main objective of the study was to compare the output and quality of yam produced by farmers as regards mulching in Osun State. The 
specific objectives were to examine the socio-economic characteristics of yam farmers; examine costs and returns to yam production; and determine the factors influencing the use of mulching in the study area.

\section{Mulching}

Mulching is a soil conservation practise. It involves the use of dry vegetable or grass materials to cover the surface of the soil. Mulch are substances spread on the ground to protect the roots and base of plants from extreme temperature, moisture changes and improve the quality of the soil and also stop the growth of weed. Mulching also enriches and protects soil and helps provide a better growing environment. Findings have shown that time of mulching can influence the growth environment and performance of yam (Dioscorea species).

Cover cropping and residue mulching are good practices for low-intensity cultivation of marginal lands to achieve soil conservation effectiveness. The rising population density, especially in south eastern Nigeria and the declining land-to-man ratio, the consequent pre-disposition of most agricultural lands to degradation, and the decline in fallow periods have driven most farmers into marginal states[14]. These new lands have been unable to support the farmers' staple food crops. As these factors impact on land-use intensification $\{[18,17,15]\}$, farmers have increasingly invested in new or borrowed technologies, thereby conserving the resource base and increasing their production $\{[15,12]\}$.

\section{Body of the Work}

\section{Research Methodology}

\section{Area of Study}

Osun state is located in the south-western part of Nigeria. It was created in 1991 and it covers an area of approximately 14,875 square kilometres. It shares common boundaries with Kwara, Ogun, Ekiti, Ondo and Oyo States. Osun state is an agrarian community. It has an estimated land area of 8 , 822.55 square kilometres. The major crops grown here are maize, yam, cassava, cocoa, oil palm, timber and tomatoes among others. The climate of Osun state is favourable for yam production. The state experiences two major seasons, the dry season and the rainy season with August break during the rainy season, the dry season is from late October/early November to march. The mean annual temperature varies $21.1^{\circ} \mathrm{C}$ to $31.1^{\circ} \mathrm{C}$. Annual rainfall is within the range of 800 $\mathrm{mm}$ in the derived savannah agro-ecology to $1500 \mathrm{~mm}$ in the rain forest belt.

\section{Sampling Technique and data}

A multi stage sampling was used to select respondents from the three agro-ecological zones in Osun state with the help of Osun state agriculture development programme (OSSADEP) office in Ife/Ijesa zone, Osogbo zone and Iwo zone. The three agro-ecological zones were chosen purposively for the study. The second stage of selection involves random selection of thirty five respondents in each of the zones consisting of adopters and non-adopters of mulching technology giving a total of one hundred and five questionnaires administered through interviews. Data was collected through the use of structured questionnaire and personal interviews between the months of September and October, 2010. Data collected included input-output information, management and production practices, costs and returns associated with yam production.

\section{Analytical Techniques}

Three main analytical methods were employed in this study: descriptive statistics, budgetary techniques and probit analysis. Descriptive statistics such as percentages, range and mean were used to describe the values of selected socioeconomic variables such as age, farm size, level of education etc. A total farm budget approach was undertaken to estimate costs and returns accruing to each of farmers. According to[4], a budget is the quantitative expression of total farm plan summarizing the income, cost and profit (a residue of total cost from total revenue). Gross margin which is the difference between total revenue and total variable cost were analysed. The total cost component is expressed as:

$$
\mathrm{TC}=\mathrm{TFC}+\mathrm{TVC}
$$

Where: $\mathrm{TC}=$ Total cost; $\mathrm{TFC}=$ Total Fixed Cost; $\mathrm{TVC}=$ Total Variable Cost

Gross margin $=(\mathrm{TR})-(\mathrm{VC}) ; \mathrm{TR}=$ Total Revenue $=$ Price

$x$ Quantity i.e. PQ

$\mathrm{VC}=$ Variable Cost Profit $=$ TR-TC

The efficiency ratios that were analysed are fixed cost ratio, rate of returns, variable to cost ratio, labour intensity amongst others. These were computed to indicate the performance of farm enterprise.

The probit model uses the cumulative distribution function (CDF) to explain the behaviour of a dichotomous dependent variable. Given the assumption of normality, the probability that $I_{i}{ }_{i}$ is less than or equal to $\mathrm{I}_{\mathrm{i}}$ can be computed from the normal $\mathrm{CDF}$ as

$$
\begin{aligned}
\mathrm{P}_{\mathrm{i}} & =\mathrm{P}(\mathrm{Y}=1 / \mathrm{X})=\mathrm{P}\left(\mathrm{I}_{\mathrm{i}}^{*}<\mathrm{I}_{\mathrm{i}}\right)=\mathrm{P}\left(\mathrm{Z}_{\mathrm{i}}<\mathrm{B}_{1+} \mathrm{B}_{2} \mathrm{X}_{\mathrm{i}}\right) \\
& =\mathrm{f}\left(\mathrm{B}_{1}+\mathrm{B}_{2} \mathrm{Xi}\right)
\end{aligned}
$$

Where $I^{*}=$ critical or threshold level of the index, such that if $I_{i}$ exceeds I*, the family will adopt, otherwise it will not. $\mathrm{P}(\mathrm{Y}=1 / \mathrm{X})$ is the probability that an event occurs given the values of $X$, or explanatory variable(s) and where $Z_{i}$ is the normal variable i.e $\mathrm{Z} \sim \mathrm{N}(0, \mathrm{Q} 2)$.

The term "probit" was coined in the 1930's by Chester Bliss and stands for probability unit. These two analyses, logit and probit, are very similar to one another. As discussed in the previously, probit uses the cumulative normal distribution. The probit model is defined as

$$
\operatorname{Pr}(\mathrm{y}=1 / \mathrm{X})=\Phi(\mathrm{xb})
$$

Where $\Phi$ is the standard cumulative normal probability distribution and $\mathrm{xb}$ is called the probit score or index.

Since $\mathrm{xb}$ has a normal distribution, interpreting probit coefficients thinking in the $\mathrm{Z}$ (normal quartile) metric. The interpretation of a probit coefficient is that one-unit increase 
in the predictor leads to increasing the probit score by $b$ standard deviations. Learning to think and communicate in the $\mathrm{Z}$ metric takes practice and can be confusing to others. We will make use of a number of tools developed by Long and Freese to aid in the interpretation of the results.

The log- likelihood function for probit is

$$
\text { In } \mathrm{L}=\sum_{\mathrm{wj}_{\mathrm{j}}} \operatorname{In} \theta\left(\mathrm{x}_{\mathrm{j}} \mathrm{b}\right)+\sum_{\mathrm{wj}} \operatorname{In}\left(1-\theta\left(\mathrm{x}_{\mathrm{j}} \mathrm{b}\right)\right.
$$

Where $w_{j}$ denotes optional weights

The model relating to the intensity of adoption is specified as follows:

Where,

$$
\begin{aligned}
\mathrm{P}_{\mathrm{i}}= & f\left(\mathrm{~B}_{0}+\mathrm{B}_{1} \mathrm{X}_{1}+\mathrm{B}_{2} \mathrm{X}_{2}+\mathrm{B}_{3} \mathrm{X}_{3}+\mathrm{B}_{4} \mathrm{X}_{4}+\mathrm{B}_{5} \mathrm{X}_{5}\right. \\
& \left.+\mathrm{B}_{6} \mathrm{X}_{6} \mathrm{~B}_{7} \mathrm{X}_{7}+\mathrm{B}_{8} \mathrm{X}_{8}+\mathrm{B}_{9} \mathrm{X}_{9}\right)
\end{aligned}
$$

$\mathrm{P}_{\mathrm{i}}=$ adoption status measured as dummy $(1=$ adopters, $0=$ non- adopters)

$\mathrm{X}_{1}=$ sex of respondents $(S E X) ; \mathrm{X}_{2}=$ Age in years $(A G E)$; $\mathrm{X}_{3}=$ Educational status $(E D U C A T I O N) ; \mathrm{X}_{4}=$ Household size $\left(\right.$ HHSIZE); $\mathrm{X}_{5}=$ Farm size $($ FARMSIZE $) ; \mathrm{X}_{6}=$ Association $(S O C K A P) ; \mathrm{X}_{7}=$ Extension visits $\left(\right.$ EXTENTI- ON); $\mathrm{X}_{8}=$ Off-farm income; $\mathrm{X}_{9}=$ Hired labour size (HRLABOUR)

\section{A Priori expectation signs of the coefficients}

The multidisciplinary independent variables included farmer, farm and institutional factors postulated to influence technology adoption. These variables include age $(A G E)$ of the household head in years, the number of people in the household (HHSIZE), measure of social interaction resulting from membership in a farmers' organization (SOCKAP), off-farm income (OFFINCOME) measured in Nigerian naira $(\AA)$, sex of the respondents (SEX), access to credit (CREDIT), education of household head (years of formal education), effective extension contacts (EXTENSION) measured by regularity of visits by extension agents, farm size, and asset. Off-farm income and assets were measured in natural logarithm. On the other hand, social capital, access to credit and extension were measured in dummies.

The rationale for inclusion of these factors was based on $a$ priori of agricultural technology adoption literature discussed in chapter 3. The effect of age $(A G E)$ on a decision whether to adopt a technology may be negative or positive. Previous studies show that the age of individuals affect there mental attitude to new ideas and influences adoption in several ways. Younger farmers have been found to be more knowledgeable about new practices and may be more willing to bear risk and adopt new technology because of their longer planning horizons. The older the farmers, the less likely they are to adopt new practices as he gains confidence in his old ways and methods. On the other hand, older farmers may have more experience, resources, or authority that may give them more possibilities for trying a new technology. Thus for this study, there is no agreement on the sign of this variable as the direction of the effect is location- or technology- specific $\{[7,11,13,6]\}$. Education (EDUCATION) was hypothesized to positively influence the adoption of integrated soil fertility technologies since as farmers acquire more of this factor, their ability to obtain, process, and use new information improves and they are likely to adopt.
Education increases the ability of farmers to use their resources efficiently and the allocative effect of education enhances the farmer's ability to obtain, analyze and interpret information. Several studies reviewed by[7], (1985) indicate the positive relationship between education and technological adoption[3], in the case of Ethiopia, reported that farmers with a higher level of education had a higher probability of adopting improved farming practices than those with lower level of education[11], in the case of Tanzania, and[13], in the case of Kenya, indicated that education is an important factor positively affecting the process of technical adoption.

Institutional factors of social capital (SOCKAP), extension contacts (EXTENSION) and access to credit (CREDIT) were hypothesized to positively influence adoption as these support services facilitate the uptake of new technologies. SOCKAP such as cooperative societies has been found to enhance the interaction and cross-fertilization of ideas among farmers. This in effect will positively affect landenhancing technologies[5]. Farmers who are non- members of associations are expected to have lower probabilities of adoption and lower level of use of ISFM technologies. The extension contact variable incorporates the information that the farmers obtain on their production activities on the importance and application of innovations through counseling and demonstrations by extension agents on regular bases. The effect of this information on adoption varies depending on channel, source, content, motivation, and frequency. It is hypothesized that the respondents who are not frequently visited by extension agents have lower possibilities of adoption than those frequently visited $\{[1,16,13,5]\}$. The variable is measured as dichotomous with respondents 'contact during the period scoring one, and zero for non-extension contact on the use of ISFM.

CREDIT takes cognizance of farmers' access to sources of credit to finance the expenses relating to adoption of innovations. Access boosts farmers' readiness to adopt technological innovations. It is hypothesized that the variable has a positive influence on the probability of the adoption and use of land enhancing technologies $\{[19,13,6]\}$. It is measured as a dichotomous variable with access being one, and zero for no access.

A measure of wealth OFFINCOME is hypothesized to positively influence adoption positively. They are generally considered to be capital that could be used either in the production process or be exchanged for cash or other productive assets. They are expected to influence the adoption of ISFM positively $\{[16,19,10]\}$. It increases the availability of capital which makes investment in land- enhancing technologies feasible. To the extent that liquidity is a constraint to adoption, OFFINCOME will have a positive effect on adoption by relaxing the constraint. The level of off-farm income, however, may not be exogenous but be affected by the profitability of the farming operation that in turn depends on technology adoption decisions. Thus, the adoption of technologies and the level of off-farm income may be determined simultaneously. The simultaneity arises due to the 
labor allocation decisions of the households about farm and non-farm activities. However, the off-farm income of the household surveyed is mostly derived from remittances of family members in non-farm business activities and from employment in non-farm sector. As the skill requirements for these jobs are likely to be different from that of farming, the farm and non-farm employment may be considered as non-competitive activities. In this situation, the level of non-farm income would be largely exogenous to the adoption decision

Household size (HHSIZE) has been identified to have either positive or negative influence on adoption $\{[9,19,13$, $5,6]\}$. Larger family size is generally associated with a greater labor force being available to the household for the timely operation of farm activities including ISFM. More labor hours will be spent on the use of technologies during labor slack seasons because of the low opportunity cost of labor in rural areas. The negative relationship of the variable with adoption has been linked to increased consumption pressure associated with large family. It is therefore difficult to predict this variable 'a priori' in this study.

Previous studies have found a positive relationship between farm size (FARMSIZE) and technological adoption $\{[9,10,13,6]\}$. Operators of large farms are likely to spend more on land-improving technologies. In many cases, large farm size is associated with increased availability of capital, which makes investment in innovations more feasible. For this analysis, farm size is included as the total cropland available to the farmer. A positive relationship is hypothesized with adoption of land-enhancing technologies. Sex is expected that male farmers will favour the adoption of improved mulching technology more than female counterparts. This is because men generally have high risk- bearing ability than their female counterparts $\{[2,3]\}$

\section{Results and Discussion}

\section{Socio-economic characteristics of respondents}

The analysis of the socio-economic characteristics of the respondents (Table 1) showed that the mean age of the adopters was 56 years and that of non-adopters was 57 years. The farm size ranges from 0.1 to 1.0 hectare with mean of 0.4 1 hectare. On the level of education, majority of the farmers had informal education. Most farmers practice mixed cropping. They intercrop maize and melon with yam. The result showed that about $36 \%$ of the respondents had adopted mulching technology. The mean household size for both adopters and non-adopters of mulching technology were 8.96 and 8.79 respectively. About $82 \%$ of the respondents were married, while others are single. The mean farming experience of the farmers was 18 years, which implies that most farmers in the area are experienced farmers. The average non-farm income for adopters and non-adopters were about $\$ 118,000$ and $\$ 103,000$, respectively. The farmers in the study area indulged in other activities like petty trading, carpentry and other artesian enterprises. It is noteworthy that farmers in the area used hired labour on their farms. The numbers of average hired labour used by an average farmer during a season were about 18 and 15 for adopters and non-adopters, respectively. This indicates that hired labour was readily available in the area for farming. Although, the labourers were non-native who came from the northern part of the country.

Table 1. Socio-economic, demographic and farm characteristics of respondents

\begin{tabular}{|c|c|c|c|}
\hline \multicolumn{4}{|c|}{ Variable Mean } \\
\hline & Adopters & Non-Adopters & All Sample \\
\hline Age & 56.03 & 56.87 & 56.45 \\
\hline Household size & 8.96 & 8.79 & 8.88 \\
\hline Farm size & 0.38 & 0.44 & 0.41 \\
\hline Non-farm income & $117,769.23$ & $103,439.72$ & $110,536.24$ \\
\hline Size of hired labour & 17.75 & 15.33 & 16.53 \\
\hline Level of experience & 12.6 & 23.3 & 17.95 \\
\hline & $\%$ & $\%$ & $\%$ \\
\hline \multicolumn{4}{|c|}{ Sex } \\
\hline Male & 92.5 & 90.4 & 91.4 \\
\hline Female & 7.5 & 9.6 & 8.6 \\
\hline \multicolumn{4}{|c|}{ Marital Status } \\
\hline Married & 81.1 & 84.7 & 82.9 \\
\hline Single & 18.9 & 15.3 & 17.1 \\
\hline \multicolumn{4}{|c|}{ Education Status } \\
\hline Formal Education & 26.4 & 36.5 & 31.4 \\
\hline No formal Education & 73.6 & 65.5 & 68.6 \\
\hline
\end{tabular}

Source: Field Survey, 2010

Table 2. Budgetary analysis per hectare of yam

\begin{tabular}{|c|c|c|c|}
\hline S/No Item & Adopters & $\begin{array}{c}\text { Non- } \\
\text { adopters }\end{array}$ & Pooled \\
\hline 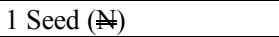 & 37086.00 & 46456.73 & 41726.78 \\
\hline 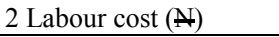 & 31240.65 & 28431.73 & 30299.05 \\
\hline 3 Total variable cost $(\mathbb{N})$ & 68326.65 & 74888.46 & 72025.83 \\
\hline 4 Total fixed cost $(\mathbb{N})$ & 17780.02 & 35480.87 & 26546.15 \\
\hline 5 Total cost $(A)$ & 86106.67 & 110369.33 & 98600.00 \\
\hline 6 Yield (kg) & 8259.4 & 6929.13 & 7600.60 \\
\hline 7 Revenue( & 412971.69 & 346456.73 & 380030.27 \\
\hline 8 Gross margin $(\mathbb{N})$ & 344645.04 & 271568.27 & 308005.12 \\
\hline 9 Net income $(\mathbb{N})$ & 326865.02 & 236087.40 & 281000.00 \\
\hline 10 Benefit-Cost Ratio & 4.79 & 3.13 & 3.85 \\
\hline
\end{tabular}

$\#$ is Naira-Nigerian currency; $¥ 1=\mathrm{US} \$ 0.0067$

Results of the budgetary analysis revealed that the proportion of labour (for adopters and non-adopters) varies (Table 2). It accounted for $36.3 \%$ and $25.8 \%$ of the total cost respectively. This may be due to extra man power requirement for mulching activities. The results further revealed that the average total revenue for adopters was $\$ 412,971.69$ while that of the non-adopters was found to be $\$ 346,456.73$. The average total variable cost for adopters and non-adopters were $\$ 68,326.65$ and $\$ 74,888.46$ respectively. Gross margin values were $\$ 334,645.04$ and $\$ 271,568.27$ for adopters and non-adopters. This implies a better performance of mulched yam that non-mulched yam. The benefit-cost ratios for the adopters and non-adopters of mulching were 4.79 and 3.13, respectively implying a better return due to adoption of mulching. 


\section{Budgetary Analysis/Hectare}

\section{The Probit Regression Result}

The result of probit regression in Table 3 showed that the log likelihood was $-23,399$ and the chi-squared value was 98.75. This implies that the model as a whole is statistically significant at 1 percent level of significance.

Table 3. Estimated probit regression

\begin{tabular}{|c|c|c|}
\hline Variables & Coefficient/se & T-ratio \\
\hline Constant & $8.227_{(2.694)}$ & 3.05 \\
\hline$S E X$ & $-0.193_{(0.581)}$ & -0.33 \\
\hline$A G E$ & $-0.249_{(0.347)}$ & -0.72 \\
\hline EDUCATION & $-0.841_{(0.565)}$ & -1.49 \\
\hline HHSIZE & $-1.221 * *_{(0.253)}$ & -4.83 \\
\hline FARMSIZE & $-0.369_{(0.311)}$ & -1.18 \\
\hline ASSOCIATION & $0.077_{(0.289)}$ & 0.27 \\
\hline EXTENSION & $0.083_{(0.697)}$ & 0.12 \\
\hline OFFARMINC & $-0.058_{(0.052)}$ & -1.11 \\
\hline HRLABOUR & $0.105 *_{(0.054)}$ & 1.93 \\
\hline \multicolumn{3}{|c|}{ Source: Field survey, 2010} \\
\hline \multicolumn{2}{|c|}{ Log likelihood $=-23.399$} & Chi-squared $=9.75$ \\
\hline \multicolumn{2}{|c|}{$* *$ significant at $1 \%$} & *Significant at $10 \%$ \\
\hline
\end{tabular}

Household size was significant at $1 \%$ level while labour hired was at $10 \%$ level. This indicates that both household size and labour hired influenced the adoption of mulching as a soil conservation technique negatively and positively respectively. This is right because both have been found to have either positive influence on adoption from previous studies (Feder et al., 1985; Nkonya et al., 1997; OluochKosura et al., 2001; Bekele and Drake, 2003). The negative coefficient of the household size implied that as the farmers household size increases there is increase in consumption pressure associated with large families and consequently decreased the respondents interests in adopting the technology.

On the other hand, the positive coefficient of the hired labour implied that greater labour force is available for timely operation of farm activities and more labour hour was spent on the use of mulching technology during labour slack season because of low opportunity cost of labour in rural areas. As a result there is this variable increase the probability of adopting mulching as a conservation technique. Age, sex, educational status, farm size, association to which farmers belonged, extension visit and off-farm income did not significantly influence adoption behaviour of farmers toward mulching technology.

\section{Conclusions}

Farmers in the study area were mostly married, middle-aged with few having formal education. An average farmer cultivated about 0.4 hectares of land with minimum land area being 0.1 hectares and the maximum 1 hectare.

Budgetary analysis revealed higher values of gross margin and net income were recorded by the adopters of the mulching technology as compared to non- adopters. The average total revenue for adopters is about $\$ 412971$ while that of non- adopters was found to be around $\$ 344$ 645.The average total cost for both adopters and non- adopters were $\$ 86106.67$ and $\$ 110339.33$ respectively. Again, the gross margin analysis showed that $\$ 344645.04$ and $\$ 271568.27$ for adopters and non- adopters respectively. The cost-benefit ratio for adopters was 4.79 while that of non-adopters is 3.13 which implies a better return to adopters of mulching technology than for non- adopters. Farmers that adopted the mulching technology were more than non-adoptive farmers in the study area. There were $50.5 \%$ adopters and $49.5 \%$ non- adopters. The result of the probit model shows that the frequency of labour hired is highly significant at 10 percent. The adoption behaviour of farmers that determines the adoption of the mulching technology is highly dependent on the total number of labour hired and household size. The negative coefficient of the household size implied that as the farmers household size increases there is increase in consumption pressure associated with large families and consequently decreased the respondents interests in adopting the technology.

There is therefore the need to encourage farmers on the needs to adopt the land protecting technology and a policy thrust that make seed yam available and affordable as well as reducing the costs incurred on labour will be in the right direction.

\section{REFERENCES}

[1] Adesina A. A. and Zinnah, M. M. 1993 "Technology Characteristics, Farmers' Perception and Adoption Decision: A Tobit Model Allocation in Sierra Leon". Agricultural Economics. 9,297-311

[2] Akinola A. A and Adeyemo R. 2008 "Adoption and Productivity of Improved Rice Varieties in Osun State, Nigeria”. Ife Journal of Agriculture. 23(1):104-116

[3] Alene, A. D., Poonyth, D and Hassan, R. M. 2000 "Determinants of Adoption and Intensity of use of Improved rice Varieties in the Central Highlands of Ethiopia: A Tobit Analysis" Agrekon (South African Journal of Agricultural Economics), 39(4):633-643

[4] Alimi, T and V. M. Manyong 2000 "Partial Budget Analysis for on-farm Research. IITA Guide no.65, Ile Ife, Nigeria. International Institute of Tropical Agriculture (IITA, 2009) annual report, Ibadan, Nigeria Nigerian National Population Commission Report, 1992

[5] Bamire, A.S. and Fabiyi, Y. L. 2002 "Adoption pattern of fertilizer technology Among farmers in the ecological zones of South-western Nigeria: A Tobit analysis". Australian journal of agricultural research. 53, 901-910

[6] Bekele, W. and Drake, L. 2003 "Soil water conservation decision and behaviour of subsistence farmers in the Eastern highlands of Ethiopia a case study of the Hunde-Lafto area.". Ecological Economics. 46(3):437-451

[7] Feder, G, Just, R. and Zilberman, D.1985 "Adoption of agricultural innovations in developing countries. A survey". 
The University of Chicago. 255 - 299

[8] IITA (2009) Improved Productivity and Increased Production from Better Roots and Tubers. International Institute of Tropical Agriculture Annual Report

[9] Manyong, V.M, Houndekon,A.V. 1997 Land Tenurial Systems and the Adoption of Mucuna Planted Fallows in the Derived Savannas of West Africa. Paper Presented at the Workshop on Property Rights Collective Action and Technology Adoption ICARD. Aleppo, Syria

[10] Negatu, W and Parikh, A. 1999 "The impact of Perception and other Factors on the Adoption of Agricultural Technologies in the Moret and Jiru Woreda (district) Ethiopia. Agricultural economics. 21, 219-229

[11] Nkoya, E., Schroeder T. and Norman, D. 1997 "Factors Affecting Adoption of Improved Maize Seed and Fertilizer in Northern Tanzania". Journal of Agricultural Economics, 4, $1-12$

[12] Olasantan, F.O. 1998 Effect of time of mulching on soil temperature and moisture regime and emergence, growth and yield of white yam in western Nigeria Department of Horticulture, University of Agriculture, P.M.B. 2240, Abeokuta, Nigeria

[13] Oluoch- Kosura, W.A, Marenya, P.P and Nzuma, M.J. 2001 "Soil fertility management in maize based production system in Kenya. Current options and the future strategies". Paper submitted at the seventh Eastern and Southern Africa regional maize conference, Nairobi. 350-355

[14] References and further reading may be available for this article. To view references and further reading you must purchase this article.Ruthernberg, H. 1977 Farming systems in the Tropics. Oxford: Clarendon Press

[15] Scoones, I., C. Reij and C. Toulmin (1996) Sustaining the soil: indigenous soil and water conservation in Africa. London: Earthscan

[16] Shiferaw, B. and Holden, S.T. 1998 "Resource degradation and the adoption of land conservation technologies in the Ethiopian highlands. A case study in Andit Tid, North Shewa". Agricultural Economics, 21, 241-256

[17] Tiffen, M., M. Mortimore and F. Gichuki 1994 "More People, Less Erosion: Environmental Recovery in Kenya". Chichester: John Wiley

[18] Turner, B., G. Hyden and R. Kates (eds.) 1993 Population growth and agricultural change in Africa. Gainsville: University of Florida Press

[19] Zeller, M. and Sharma, M. 1998 "Rural Finance and Poverty Alleviation". Food Policy Report, International Food Policy Research Institute, Washinton, D. C. June 1998:1-32 